ACTA UNIVERSITATIS WRATISLAVIENSIS

PRZEGLĄD PRAWA I ADMINISTRACJI CXX/2

WROCŁAW 2020

https://doi.org/10.19195/0137-1134.120.92

\author{
JACEK BOROWICZ \\ ORCID: 0000-0002-1833-4020 \\ Uniwersytet Wrocławski \\ Instytut Prawa Cywilnego \\ Zakład Prawa Pracy
}

\title{
SYTUACJA PRAWNA INSPEKTORA OCHRONY DANYCH ZATRUDNIONEGO W RAMACH STOSUNKU PRACY - WYBRANE ZAGADNIENIA
}

\begin{abstract}
Abstrakt: Przepisy art. 37 ust. 1 rozporządzenia (UE) 2016/679 Parlamentu Europejskiego i Rady z dnia 27 kwietnia 2016 roku w sprawie ochrony osób fizycznych w zakresie przetwarzania danych osobowych i swobodnego przepływu tych danych oraz uchylającego dyrektywę 95/46/WE (RODO) nakładają na wymienione w nim kategorie administratorów danych i podmiotów przetwarzających dane obowiązek wyznaczania inspektora ochrony danych. Zgodnie z przepisami art. 37 ust. 6 RODO inspektor ochrony danych może być członkiem personelu administratora lub podmiotu przetwarzającego lub wykonywać zadania na podstawie umowy o świadczenie usług. Ani przepisy RODO, ani obowiązująca ustawa z dnia 10 maja 2018 roku o ochronie danych osobowych nie określają formy prawnej zatrudnienia inspektora ochrony danych jako członka personelu tych podmiotów. Należy zatem przyjąć, że jest on zatrudniany na podstawie umowy o pracę jako pracownik w rozumieniu przepisów ustawy z dnia 26 czerwca 1974 roku Kodeks pracy. Przepisy RODO określają szczególne miejsce inspektora w strukturze organizacyjnej podmiotu, w którym przetwarzane są dane osobowe. Podlegać ma on bezpośrednio najwyższemu kierownictwu tego podmiotu (na przykład kierownikowi jednostki organizacyjnej lub osobie fizycznej będącej administratorem danych osobowych). Inspektor ochrony danych osobowych zachowuje szeroką autonomię w zakresie wykonywania przypisanych mu przez prawo obowiązków, pracodawca zaś jest zobowiązany zapewnić mu niezależność w związku z ich wykonywaniem, powstrzymując się od wydawania mu instrukcji dotyczących wykonywania tych zadań. Na mocy przepisów prawa następuje zatem ograniczenie możliwości zarządzania pracą inspektora ochrony danych przez wydawanie mu poleceń dotyczących pracy. $\mathrm{Z}$ tego względu należy uznać, że inspektor ochrony danych jest zatrudniony w ramach tak zwanego nietypowego stosunku pracy.
\end{abstract}

Słowa kluczowe: RODO, ochrona danych osobowych, inspektor ochrony danych, administrator danych osobowych, pracownik, pracodawca, obowiązek wykonywania poleceń pracodawcy, nietypowy stosunek pracy 


\section{EWOLUCJA SYTUACJI PRAWNEJ PODMIOTU PEŁNIĄCEGO U ADMINISTRATORA DANYCH OSOBOWYCH FUNKCJE ZWIĄZANE Z ZAPEWNIENIEM BEZPIECZEŃSTWA DANYCH OSOBOWYCH}

Regulacja prawna sytuacji podmiotu pełniącego u administratora danych osobowych funkcje związane $\mathrm{z}$ zapewnieniem bezpieczeństwa danych osobowych ewoluowała w ciągu lat obowiązywania w Polsce przepisów ustawy z dnia 29 sierpnia 1997 roku o ochronie danych osobowych ${ }^{1}$ (dalej: u.o.d.o. 1997). Ustawa w swojej wersji pierwotnej nie przewidywała obowiązku lub możliwości zatrudniania $u$ administratora danych osobowych osoby wykonującej wyspecjalizowane zadania związane $\mathrm{z}$ ochroną danych osobowych. Kwestię tę rozstrzygały natomiast przepisy wykonawcze. Zgodnie zatem z przepisami rozporządzenia Ministra Spraw Wewnętrznych i Administracji z dnia 3 czerwca 1998 roku w sprawie określenia podstawowych warunków technicznych i organizacyjnych, jakim powinny odpowiadać urządzenia i systemy informatyczne służące do przetwarzania danych osobowych ${ }^{2}$, administrator danych osobowych w związku z przetwarzaniem przez siebie tych danych wypełniać miał wiele szczegółowych obowiązków formalnych, organizacyjnych, technicznych i personalnych - w ramach tych ostatnich wskazując administratora bezpieczeństwa informacji (dalej: a.b.i.), o zakresie zadań wyznaczonym ramowo przepisami tego rozporządzenia. Zgodnie $\mathrm{z}$ jego $\S 3$ a.b.i. był osobą odpowiedzialną za bezpieczeństwo danych osobowych w systemie informatycznym, w tym w szczególności za przeciwdziałanie dostępowi osób niepowołanych do systemu, w którym przetwarzane są dane osobowe, oraz za podejmowanie odpowiednich działań w przypadku wykrycia naruszeń w systemie zabezpieczeń. Rozporządzanie nie zawierało szczegółowych przepisów precyzujących sytuację prawną a.b.i. W ówczesnej literaturze wyrażano natomiast pogląd, że funkcję tę pełnić może zarówno osoba usytuowana wewnątrz struktury administratora danych osobowych, jak i osoba lub podmiot z zewnątrz ${ }^{3}$. W 2004 roku zmieniono brzmienie art. 36 u.o.d.o. 1997 przez dodanie do niego ust. 3 nakładającego na administratora danych osobowych wyraźny obowiązek „wyznaczania” administratora bezpieczeństwa informacji ${ }^{4}$. Obowiązek taki nie dotyczył jednak sytuacji, w której administrator danych osobowych sam wykonywał obowiązki przepisywane a.b.i. Przepis ten nie przesądzał kwestii, w ramach jakiego stosunku prawnego a.b.i. wykonywać ma swoje obowiązki

1 Tekst pierwotny Dz.U.1997.133.883.

2 Dz.U.1998.80.521.

3 Tak wskazywał na przykład A. Mednis, Ustawa o ochronie danych osobowych. Komentarz, Warszawa 1999, s. 114.

${ }^{4}$ Zmianę wprowadzała ustawa $\mathrm{z}$ dnia 22 stycznia 2004 roku o zmianie ustawy o ochronie danych osobowych oraz ustawy o wynagrodzeniu osób zajmujących kierownicze stanowiska państwowe, tekst jedn. Dz.U.2004.33.285. 
u administratora danych osobowych. Jak w związku z tym wskazywał A. Drozd, podstawą ich wykonywania mogły być rozmaite stosunki zatrudnienia, takie jak stosunek pracy, stosunki cywilnoprawne oraz stosunki administracyjnoprawne. Autor dopuszczał możliwość wykonywania czynności a.b.i. także przez przedsiębiorcę, w ramach samozatrudnienia, lub przez pracownika pracodawcy innego niż administrator danych osobowych ${ }^{5}$. Kolejny ważny etap ewolucji sytuacji prawnej podmiotu pełniącego $\mathrm{u}$ administratora danych osobowych funkcje związane z zapewnieniem bezpieczeństwa danych osobowych wyznaczyła nowelizacja u.o.d.o. 1997, wchodząca w życie dnia 1 stycznia 2015 roku$^{6}$. Wprowadziła ona daleko bardziej rozbudową i szczegółową regulację prawną tej kwestii. Zgodnie z art. 36a ust. 1 znowelizowanej u.o.d.o. 1997 administrator danych osobowych mógł ,powołać administratora bezpieczeństwa informacji”. W dalszych przepisach ustawa ta określała między innymi szczegółowe zadania a.b.i. (art. 36a ust. 2 i ust. 4 u.o.d.o. 1997) oraz, w sposób zbliżony do pragmatyk pracowniczych, wymogi, jakie spełniać miała osoba fizyczna powoływana do pełnienia tej funkcji (art. 36a ust. 5 u.o.d.o. 1997). Znowelizowana ustawa określała także szczególną, niezależną pozycję organizacyjną a.b.i. w podmiocie przetwarzającym dane osobowe jako osoby podległej bezpośrednio kierownikowi jednostki organizacyjnej lub osobie fizycznej będącej administratorem danych (art. 36a. ust. 6-8 u.o.d.o. 1997)7. Dawało to podstawę do formułowania w literaturze poglądów o wykreowaniu przez ustawodawcę nowego, samodzielnego zawodu a.b.i. o charakterystyce zbliżonej do pewnego stopnia do zawodu regulowanego w rozumieniu przepisów prawa ${ }^{8}$. W ówczesnej literaturze podkreślano ponadto, że w obowiązującym wtedy stanie prawnym powołanie a.b.i., jako uprawnienie administratora danych osobowych

5 Tak na temat ówczesnej pozycji a.b.i. pisał A. Drozd, Ustawa o ochronie danych osobowych. Komentarz. Wzory pism i przepisy, Warszawa 2004, s. 252 n., podejmując także dokładniejsze rozważania na ten temat.

${ }^{6}$ Zmiany w u.o.d.o. 1997 wprowadzono ustawą z dnia 7 listopada 2014 roku o ułatwieniu wykonywania działalności gospodarczej, art. 9 (tekst jedn. Dz.U.2014.1662).

7 Ustawa z dnia 29 sierpnia 1997 roku o ochronie danych osobowych w wersji opublikowanej jako tekst jedn. Dz.U.2016.922. Ponadto zgodnie z upoważnieniem zawartym w art. 36a. ust. 9 u.o.d.o. Minister Administracji i Cyfryzacji określił między innymi tryb i sposób realizacji zadań a.b.i., wydając rozporządzenie z dnia 11 maja 2015 roku w sprawie sposobu prowadzenia przez administratora bezpieczeństwa informacji rejestru zbiorów danych (Dz.U.2015.719) oraz rozporządzenie z dnia 11 maja 2015 roku w sprawie trybu i sposobu realizacji zadań w celu zapewniania przestrzegania przepisów o ochronie danych osobowych przez administratora bezpieczeństwa informacji (Dz.U.2015.745). Aktualność odnośnie do skonkretyzowania zadań a.b.i. zachowywało także wcześniejsze rozporządzenie Ministra Spraw Wewnętrznych i Administracji z dnia 29 kwietnia 2004 roku w sprawie dokumentacji przetwarzania danych osobowych oraz warunków technicznych i organizacyjnych, jakim powinny odpowiadać urządzenia i systemy informatyczne służące do przetwarzania danych osobowych (Dz.U.2004.100.1024).

8 Zob. więcej J. Borowicz, Z problematyki zatrudnienia administratora bezpieczeństwa informacji, „Praca i Zabezpieczenie Społeczne” 2016, nr 12, s. 22-23. 
miało charakter fakultatywny ${ }^{9}$. Jednocześnie zauważano, że działanie administratora danych osobowych określane w znowelizowanej u.o.d.o. 1997 jako „powołanie" a.b.i. nie może być utożsamiane z powołaniem - podstawą nawiązania stosunku pracy wymienioną w art. 2 k.p. ustawy z dnia 26 czerwca 1974 roku Kodeks pracy (dalej: k.p.) ${ }^{10}$. Działanie to należało traktować w kategoriach czynności organizacyjnej administratora danych osobowych, który wyznacza/wskazuje/wybiera konkretną osobę fizyczną spełniającą wymogi określone w ustawie do pełnienia wynikających z niej zadań a.b.i. Podtrzymywano w związku z tym wcześniejsze poglądy, że w konkretnym przypadku wykonywanie zadań a.b.i. u danego administratora danych osobowych może odbywać się w ramach zatrudnienia pracowniczego (przez pracownika w rozumieniu k.p. zatrudnionego na podstawie umowy o pracę) czy też służbowego (administracyjnoprawnego).W odniesieniu do kwestii dopuszczalności zatrudnienia cywilnoprawnego a.b.i. podnoszono konieczność nawiązywania względnie trwałych i długoterminowych relacji ze względu na konieczność zapewnienia ciągłości wykonywania przypisanych mu zadań. Podnoszono to także w odniesieniu do powierzania zadań a.b.i. indywidualnemu przedsiębiorcy (przy założeniu, że jako osoba fizyczna spełniał on wymogi stawiane przez ustawę kandydatom na a.b.i. $)^{11}$.

Współcześnie podstawowymi aktami prawnymi określającymi sytuację prawną podmiotu wykonującego $\mathrm{u}$ administratora danych osobowych zadania związane z zapewnieniem bezpieczeństwa danych osobowych są: rozporządzenie Parlamentu Europejskiego i Rady (UE) 2016/679 z dnia 27 kwietnia 2016 roku w sprawie ochrony osób fizycznych w związku z przetwarzaniem danych osobowych i w sprawie swobodnego przepływu takich danych oraz uchylenia dyrektywy 95/46/WE 12 (dalej: RODO) oraz ustawa z dnia 10 maja 2018 roku o ochronie danych osobowych ${ }^{13}$ (dalej: u.o.d.o). Przepisy tej ostatniej wprowadziły między innymi zmianę terminologiczną, zastępując stosowane do tej pory w prawie polskim określenie ,administrator bezpieczeństwa informacji” terminem „,inspektor ochrony danych" (dalej: i.o.d.), zapewniając tym samym spójność pojęciową prawa polskiego i RODO ${ }^{14}$.

9 Zob. na przykład ibidem, s. 17 n. i przytaczana tam literatura przedmiotu.

10 Tekst jedn. Dz.U.2019.1040.

11 Zob. więcej J. Borowicz, op. cit.

12 Dz. Urz. UE L 119/1 z dnia 4 maja 2016 roku.

13 Tekst jedn. Dz.U.2019.1781.

14 Angielskojęzyczna wersja RODO posługuje się w analizowanych w niniejszym opracowaniu przepisach określeniem „the data protection officer”. Warto zauważyć, że w popularnych thumaczeniach zautomatyzowanych jest ono przekładane jako ,inspektor ochrony danych”, zob. na przykład https://www.deepl.com/pl/translator\#en/pl/\%E2\%80\%9Ethe\%20data $\% 20$ protection $\% 20$ officer $\% \mathrm{E} 2 \% 80 \% 9 \mathrm{D}$; https://translate.google.pl/?hl=pl\#view=home\&op=translate\&sl=auto\&tl=pl\&text=the $\% 20$ data $\% 20$ protection $\% 20$ officer (dostęp: 20.01.2020). 


\section{PRACODAWCA JAKO PODMIOT ZATRUDNIAJACCY INSPEKTORA OCHRONY DANYCH}

Wyznaczenie i.o.d. w obecnym stanie prawnym jest obligatoryjne lub fakultatywne. $\mathrm{W}$ świetle przepisu art. 8 u.o.d.o. podmiotami zobowiązanymi do wyznaczenia i.o.d. w przypadkach i na zasadach określonych w art. 37 RODO są administrator danych osobowych i podmiot przetwarzający dane ${ }^{15}$. Zgodnie $\mathrm{z}$ art. 37 ust. 1 RODO te podmioty wyznaczają inspektora, zawsze gdy: a) przetwarzania dokonują organ lub podmiot publiczny, z wyjątkiem sądów w zakresie sprawowania przez nie wymiaru sprawiedliwości; b) główna działalność administratora lub podmiotu przetwarzającego polega na operacjach przetwarzania, które ze względu na swój charakter, zakres lub cele wymagają regularnego i systematycznego monitorowania osób, których dane dotyczą, na dużą skalę; lub c) główna działalność administratora lub podmiotu przetwarzającego polega na przetwarzaniu na dużą skalę szczególnych kategorii danych osobowych, o których mowa w art. 9 RODO, lub danych osobowych dotyczących wyroków skazujących i czynów zabronionych, o czym mowa w art. 10 RODO $^{16}$. Ustawodawca krajowy doprecyzował $\mathrm{w}$ art. 9 u.o.d.o., że przez organy i podmioty publiczne obowiązane do wyznaczenia i.o.d., o których mowa $\mathrm{w}$ art. 37 ust. 1 lit. a RODO, rozumie się: 1. jednostki sektora finansów publicznych ${ }^{17} ; 2$. instytuty badawcze ${ }^{18} ; 3$. Narodowy Bank Polski $^{19}$. Zgodnie $\mathrm{z}$ art. 37 ust. 4 RODO, zdanie pierwsze, w przypadkach innych niż wskazane administrator, podmiot przetwarzający, zrzeszenia lub inne podmioty reprezentujące określone kategorie administratorów albo podmiotów przetwarzających mogą wyznaczyć lub jeżeli wymaga tego prawo Unii lub prawo państwa członkowskiego, wyznaczają i.o.d.

15 Zgodnie przepisami art. 4 pkt 7 RODO definiującym podstawowe pojęcia w nim używane „administrator” oznacza osobę fizyczną lub prawną, organ publiczny, jednostkę lub inny podmiot, który samodzielnie lub wspólnie z innymi ustala cele i sposoby przetwarzania danych osobowych; jeżeli cele i sposoby takiego przetwarzania są określone w prawie Unii lub w prawie państwa członkowskiego, to również w prawie Unii lub w prawie państwa członkowskiego może zostać wyznaczony administrator lub mogą zostać określone konkretne kryteria jego wyznaczania. Zgodnie z art. 4 pkt 8 RODO określenie ,podmiot przetwarzający” oznacza osobę fizyczną lub prawną, organ publiczny, jednostkę lub inny podmiot, który przetwarza dane osobowe w imieniu administratora.

16 Przepisy art. 9 RODO dotyczą przetwarzania szczególnych kategorii danych osobowych, tak zwanych danych wrażliwych. Art. 10 RODO określa warunki dopuszczalności przetwarzania danych osobowych dotyczących wyroków skazujących oraz naruszeń prawa lub powiązanych środków bezpieczeństwa.

17 Zob. podmioty wymienione w art. 9 ustawy z dnia 27 sierpnia 2009 roku o finansach publicznych, tekst jedn. Dz.U.2019.869.

18 Tworzone i funkcjonujące zgodnie z przepisami ustawy z dnia 30 kwietnia 2010 roku o instytutach badawczych, tekst jedn. Dz.U.2019.1350.

19 Zob. ustawa z dnia 29 sierpnia 1997 roku o Narodowym Banku Polskim, tekst jedn. Dz.U.2019.1810. 
Należy podtrzymać wyrażony we wcześniejszej literaturze pogląd, uznając, że także w obecnym stanie prawnym przyjęte w RODO określenia administratora danych (i podmiotu przetwarzającego) są wystarczająco pojemne, aby objąć nimi pojęcie pracodawcy w rozumieniu art. 3 k.p. ${ }^{20}$ Pracodawca może występować jako administrator danych osobowych lub podmiot przetwarzający dane w dwóch przypadkach - jako podmiot przetwarzający na zasadach określonych w przepisach k.p. dane osobowe kandydatów do pracy i dane osobowe zatrudnianych przez siebie pracowników oraz jako podmiot przetwarzający dane osobowe innych osób fizycznych w związku z prowadzoną przez siebie działalnością, w szczególności jako jeden z podmiotów wymienionych $w$ art. 37 ust. 1 RODO ${ }^{21}$. Jako taki, wyznaczając i zatrudniając i.o.d. w ramach stosunku pracy, staje się dla niego pracodawcą $w$ rozumieniu art. 3 k.p.

\section{PODSTAWA PRAWNA ZATRUDNIENIA INSPEKTORA OCHRONY DANYCH OSOBOWYCH}

Podejmując zamiar ustalenia podstaw prawnych wykonywania funkcji i.o.d. i w tym zakresie podstaw prawnych jego zatrudnienia, za znamienne należy uznać, że w preambule RODO (motyw 97) prawodawca unijny stwierdza między innymi, że inspektorzy ochrony danych — bez względu na to, czy są pracownikami administratora - powinni być w stanie wykonywać swoje obowiązki i zadania w sposób niezależny. Następnie należy wskazać, że zgodnie z formułą przyjętą zarówno w art. 37 ust. 1 RODO, jak i art. 8 u.o.d.o. administrator danych osobowych i podmiot przetwarzający, którzy są do tego zobowiązani, „wyznaczają inspektora ochrony danych”. Uwagę zwracać może wzmiankowanie w art. 38 ust. 3 RODO $i$ art. 10 ust. 4 u.o.d.o. o sytuacji odwołania inspektora. W świetle zaś z kolei art. 37 ust. 6 RODO wyróżnić należy sytuację, w której inspektor ochrony danych jest ,,członkiem personelu administratora lub podmiotu przetwarzającego", i sytuację, w której wykonuje on swoje zadania „na podstawie umowy o świadczenie usług”. Konsekwencją wyznaczenia i.o.d. jest zatem albo włączenie go w skład personelu administratora danych osobowych lub podmiotu przetwarzającego dane - albo powierzenie mu jego zadań na podstawie umowy o świadczenie usług. O ile wskazanie umowy o świadczenie usług jako podstawy prawnej wykonywania zadań i.o.d. wydaje się nie budzić wątpliwości interpretacyjnych, to wyjaśnienia wymaga sytuacja wyznaczania i.o.d. skutkująca włączeniem go do personelu administratora danych osobowych lub podmiotu przetwarzającego dane. Należy zauważyć, że termin ,personel” nie zostaje w tym wypad-

20 J. Borowicz, op. cit., s. 18.

21 Zob. rozważania J. Borowicza prowadzone na gruncie poprzednio obowiązującego stanu prawnego, idem, Sytuacja prawna pracownika przetwarzajacego dane osobowe w ramach wykonywania obowiąków ze stosunku pracy, [w:] Z aktualnych problemów prawa pracy i prawa socjalnego, red. H. Szurgacz, („Prawo” 307), Wrocław 2009, s. 13. 
ku prawnie zdefiniowany. Odwołując się do potocznego, językowego kręgu znaczeń z nim wiązanych, należy wskazać, że „personel” to „zespół pracowników w biurze, instytucji, sklepie itp.”22 lub, bardziej precyzyjnie, „zespół pracowników jakiejś instytucji, najczęściej publicznej, których celem jest wykonywanie ściśle określonych zadań nienależących do kierownika tej instytucji”"23. Termin ,personel” funkcjonuje w języku polskim także jako synonim „,pracowników”, ,załogi”, „obsady”, „osób zatrudnianych”, „,ogółu pracowników”, „grupy osób pracujących w jednym miejscu” lub „kadry pracowniczej” ${ }^{24}$. Dostrzegalne jest zatem, że potoczne rozumienie terminu „personel” akcentuje z jednej strony jego aspekt zbiorowy (różnie określana zbiorowość ludzi wykonujących wspólnie pracę w ramach jakiejś struktury organizacyjnej), z drugiej zaś status pracowniczy członków personelu. Jednocześnie należy podkreślić, że przytaczany motyw 97 preambuły RODO wprost wskazuje, że w intencji prawodawcy unijnego osoby fizyczne, zatrudniane jako inspektorzy ochrony danych, mogą mieć w szczególności status pracowników ${ }^{25}$. Pozwala to sformułować wniosek, że i.o.d. pełni swą funkcję albo na zasadach pracowniczych, w ramach stosunku pracy, albo na podstawie umowy o świadczenie usług ${ }^{26}$. W związku z brakiem szczególnej definicji pojęcia pracownika należy się w tym względzie odwołać do przepisów krajowych, przyjmując jego rozumienie wynikające z przepisów kodeksu pracy. Zgodnie $\mathrm{z}$ art. $2 \mathrm{k}$.p. pracownikiem jest zatem osoba zatrudniona na podstawie umowy o pracę, powołania, wyboru, mianowania lub spółdzielczej umowy o pracę. Przepisy określające status i.o.d. nie wskazują podstawy prawnej nawiązania z nim stosunku pracy. Odnosząc się w tym zakresie do ustalenia treści pojęć „,wyznaczania” lub „włączania do personelu”, należy przyjąć, że oznaczają one pewne czynności technicznoorganizacyjne pracodawcy związane z wyborem lub wskazaniem konkretnej, spełniającej wymogi osoby fizycznej, która ma być zatrudniona na stanowisku pracy i.o.d. ${ }^{27} \mathrm{~W}$ szczególności pojęciu wyznaczania należy przypisać rozumienie potoczne, łącząc je z działaniami, w wyniku których danej osobie zostaje powierzona

${ }^{22}$ Zob. na przykład https://sjp.pwn.pl/sjp/personel;2571286.html (dostęp: 23.01.2020).

23 Ibidem.

${ }^{24}$ Zob. na przykład https://www.synonimy.pl/synonim/personel/; https://synonim.net/syno$\mathrm{nim} /$ personel (dostęp: 23.01.2020).

25 W wersji angielskojęzycznej używane jest określenie „an employee” (,,Such data protection officers, whether or not they are a n e m p lo y e e of the controller") podlegające jednoznacznemu thumaczeniu na język polski jako ,pracownik”.

26 Tak też jednoznacznie przyjmuje P. Fajgielski, stwierdzając, że inspektor ochrony danych może być pracownikiem albo może sprawować tę funkcję w ramach umowy cywilnoprawnej, zob. idem, Komentarz do rozporzadzenia $n r$ 2016/679 w sprawie ochrony osób fizycznych w zwiaz$k u$ z przetwarzaniem danych osobowych $i w$ sprawie swobodnego przeptywu takich danych oraz uchylenia dyrektywy 95/46/WE (ogólne rozporządzenie o ochronie danych), art. 37, [w:] Ogólne rozporzadzenie o ochronie danych. Ustawa o ochronie danych osobowych. Komentarz, https://sip. lex.pl/\#/commentary/587773181/570621 (dostęp: 27.01.2020).

27 Lub z którą w innym układzie organizacyjnym zostanie zawarta umowa o świadczenie usług. 
jakaś funkcja, stanowisko, zadanie ${ }^{28}$. W tym sensie w zakresie wyznaczania i włączania do personelu mieszczą się między innymi działania określane w zarządzaniu zasobami ludzkimi jako rekrutacja i selekcja kandydatów do pracy czy też awans pionowy lub poziomy w ramach danej struktury organizacyjnej. Konsekwencją wyznaczenia może być zatem albo włączenie w skład personelu administratora danych przez zatrudnienie danej osoby jako pracownika na stanowisku i.o.d., albo też powierzenie zadań i.o.d. pracownikowi już zatrudnionemu u tego administratora na innym stanowisku pracy. To ostatnie oznaczać może z kolei albo sytuację łączenia na polecenie pracodawcy obowiązków i.o.d. z obowiązkami dotychczasowymi na danym stanowisku pracy (jeśli byłoby to w świetle przepisów prawa akceptowalne), albo sytuację awansu poziomego lub pionowego i podjęcia obowiązków pracy na stanowisku i.o.d. przez pracownika zatrudnianego do tej pory na innym stanowisku pracy (zmiana rodzaju pracy umówionej) ${ }^{29}$.

W określeniu podstawy nawiązania stosunku pracy z i.o.d. należy podnieść przede wszystkim, że incydentalne zastosowanie w art. 38 ust. 3 RODO i art. 10 ust. 4 u.o.d.o sformułowań wskazujących na sytuację „odwołania” i.o.d. nie może być interpretowane w ten sposób, że wcześniej ów inspektor został zatrudniony na podstawie powołania $\mathrm{w}$ rozumieniu przepisów art. 2 k.p. ${ }^{30}$ Zgodnie z art. $68 \S 1$ k.p. stosunek pracy nawiązuje się na podstawie powołania w przypadkach określonych w odrębnych przepisach. Przepisy te muszą zatem wprost wskazywać na powołanie jako podstawę nawiązania stosunku pracy z danym pracownikiem ${ }^{31}$. Sytuacja taka nie występuje w przypadku i.o.d. Właściwą podstawą nawiązania z nim stosunku pracy będzie zatem umowa o pracę ${ }^{32}$. W treści umowy o pracę stro-

28 Podkreśla to na przykład E. Bielak-Jomaa, Art. 37, [w:] RODO. Ogólne rozporządzenie o ochronie danych. Komentarz, https://sip.lex.pl/\#/commentary/587747178/544618 (dostęp: 27.01.2020).

29 Tak wskazywano też na gruncie przepisów u.o.d.o. 1997, zob. J. Borowicz, Z problematyki..., s. 18. Na gruncie obecnego stanu prawnego E. Bielak-Jomaa, odnosząc się z aprobatą do rezygnacji ze stosowania w przepisach prawa zwrotu wskazującego na powołanie i.o.d., podkreśla, że „z praktycznego punktu widzenia wydaje się, że najistotniejsze jest wykazanie dokonania czynności wyznaczenia i przyjęcia funkcji przez wyznaczoną osobę. Formą wyznaczenia może być więc umowa o pracę, w przypadku zatrudnienia w celu pełnienia funkcji IOD — aneks do umowy powierzający pełnienie tej funkcji albo zawarcie odrębnej umowy w przypadku innej podstawy świadczenia pracy", eadem, op. cit.

${ }^{30} \mathrm{~W}$ poprzednio obwiązujących przepisach u.o.d.o. 1997 ustawodawca określał w art. 36a ust. 1, że administrator danych „może p o w oł a ć [podkr.- J.B.] administratora bezpieczeństwa informacji”.

31 Warto ponadto podkreślić, że powołanie jako podstawa nawiązania stosunku pracy ma typowo zastosowanie do obsadzania stanowisk kierowniczych. Zob. tytułem przykładu przepisy ustawy z dnia 30 kwietnia 2010 roku o instytutach badawczych, tekst jedn. Dz.U.2019.1350, wskazują że dyrektora takiego instytutu oraz jego zastępcę powołuje i odwołuje minister nadzorujący dany instytut (art. 24 ust. 1 pkt 2, art. 27 ust. 1 ustawy).

${ }^{32} \mathrm{Na}$ gruncie poprzednio obowiązującego stanu prawnego wskazywano, że gdy pracodawca powołuje jako a.b.i. swojego aktualnego pracownika, to może mieć do czynienia nie tylko z osobą zatrudnioną przez siebie na podstawie umowy o pracę, lecz także z pracownikiem zatrudnionym 
ny ustalają w szczególności rodzaj pracy umówionej. Należy uznać, że w związku $\mathrm{z}$ istnieniem przepisów prawa określających podstawowe zadania i.o.d. wystarczające jest wskazanie w treści takiej umowy o pracę tak właśnie nazwanego stanowiska pracy (inspektor ochrony danych). Można uznać, że w przypadku i.o.d. mamy do czynienia z zawodem o przedmiocie prawnie definiowanym. Zgodnie $\mathrm{z}$ art. 39 ust. 1 RODO inspektor ochrony danych ma następujące zadania: a) informowanie administratora, podmiotu przetwarzającego oraz pracowników, którzy przetwarzają dane osobowe, o obowiązkach spoczywających na nich na mocy niniejszego rozporządzenia oraz innych przepisów Unii lub państw członkowskich o ochronie danych i doradzanie im w tej sprawie; b) monitorowanie przestrzegania niniejszego rozporządzenia, innych przepisów Unii lub państw członkowskich o ochronie danych oraz polityk administratora lub podmiotu przetwarzającego w dziedzinie ochrony danych osobowych, w tym podział obowiązków, działania zwiększające świadomość, szkolenia personelu uczestniczącego w operacjach przetwarzania oraz powiązane z tym audyty; c) udzielanie na żądanie zaleceń co do oceny skutków w kwestii ochrony danych oraz monitorowanie jej wykonania zgodnie $\mathrm{z}$ art. $35^{33}$; d) współpraca $\mathrm{z}$ organem nadzorczym; e) pełnienie funkcji punktu kontaktowego organu nadzorczego w kwestiach związanych z przetwarzaniem, w tym z uprzednimi konsultacjami, o których mowa w art. $36^{34}$, oraz w stosownych przypadkach prowadzenie konsultacji we wszelkich innych sprawach.

Zgodnie z art. 38 ust. 6 RODO inspektor ochrony danych może wykonywać inne zadania i obowiązki. Pracodawca w takiej sytuacji ma obowiązek zapewnić, by takie zadania i obowiązki nie powodowały konfliktu interesów. Należy zatem w szczególność uznać, że ze względów praktycznych wykonywanie innych zadań i obowiązków nie może utrudniać lub uniemożliwiać spełniania zadań przypisanych i.o.d. w ich aspekcie organizacyjnym (na przykład uwzględniać trzeba niezbędny czas na wykonywanie zadań inspektora czy też konieczność przemieszczania się i uzyskiwania dostępu do miejsc, w których zadania te mają być realizowane a wszystko to przy uwzględnieniu sytuacji nagłych, mogących wystąpić w różnym czasie i w różnych miejscach struktury organizacyjnej zakładu pracy, a związa-

na innej z podstaw nawiązania stosunku pracy wymienionych w art. 2 k.p. Co do zasady dopuścić zatem można sytuację, w której do pełnienia funkcji a.b.i. wyznaczony zostaje przez pracodawcę pracownik już zatrudniony na postawie umowy o pracę czy spółdzielczej umowy o pracę, ale też mianowania, wyboru lub... powołania; zob. J. Borowicz, Z problematyki...

33 Przepisy art. 35 ust. 1-11 RODO określają szczegółowe zasady oceny przez administratora danych skutków planowanych operacji przetwarzania dla ochrony danych osobowych w sytuacji wysokiego ryzyka naruszenia praw lub wolności osób fizycznych. Warto podkreślić, że jeżeli $\mathrm{u}$ danego administratora został wyznaczony inspektor ochrony danych, to administrator powinien konsultować się z nim, dokonując oceny tych skutków dla ochrony danych.

34 Zgodnie z art. 36 ust. 1 RODO jeżeli ocena skutków dla ochrony danych, o której mowa w art. 35, wskaże, że przetwarzanie powodowałoby wysokie ryzyko, gdyby administrator nie zastosował środków w celu zminimalizowania tego ryzyka, to przed rozpoczęciem przetwarzania administrator konsultuje się z organem nadzorczym. 
nych z nieprzewidywanym zagrożeniem bezpieczeństwa danych). Łączenie funkcji i.o.d. z innymi zadaniami może też komplikować kwestie podległości organizacyjnej danego pracownika, gdy jako inspektor powiązany będzie on bezpośrednio z podmiotem zarząadzającym zakładem pracy w imieniu pracodawcy (ponieważ „podlega najwyższemu kierownictwu” — art. 38 ust. 3. RODO), jednocześnie podlegając hierarchicznie co do reszty zadań innemu przełożonemu zainteresowanemu przede wszystkim realizacją zadań przypisanych kierowanej przez siebie komórce organizacyjnej. W literaturze podkreśla się więc, że wymóg niepowodowania konfliktu interesów określony w art. 38 ust. 6, zdanie drugie RODO jest ściśle związany $\mathrm{z}$ wymogiem wykonywania zadań w sposób niezależny ${ }^{35}$.

Ze względu na specyfikę prawnie określonego zestawu zadań i.o.d. należy uznać, że nawiązanie $\mathrm{z}$ daną osobą stosunku pracy na podstawie umowy o pracę na takim stanowisku musi się wiązać z udzieleniem jej przez pracodawcę formalnego pisemnego upoważnienia do dostępu do danych osobowych przetwarzanych u tego pracodawcy ${ }^{36}$. Ma to znaczenie w szczególności także w przypadku powierzenia zadań określonych $\mathrm{w}$ art. 39 ust. 1 RODO pracownikowi już zatrudnionemu $\mathrm{u}$ danego pracodawcy, jeżeli w związku z pracą dotychczasową nie miał takiego upoważnienia lub dysponował nim, ale w zakresie innym niż niezbędny do pełnienia zadań i.o.d. u tego pracodawcy.

\section{PODPORZĄDKOWANIE PRACOWNICZE INSPEKTORA OCHRONY DANYCH OSOBOWYCH}

Zgodnie z art. $22 \S 1$ k.p. przez nawiązanie stosunku pracy pracownik zobowiązuje się do wykonywania pracy określonego rodzaju na rzecz pracodawcy i pod jego kierownictwem oraz w miejscu i czasie wyznaczonym przez pracodawcę, a pracodawca - do zatrudniania pracownika za wynagrodzeniem. Wykonywanie pracy pod kierownictwem pracodawcy jest jednym z elementów definiujących

35 Jak wskazuje E. Bielak-Jomaa, i.o.d. „nie może zajmować w organizacji stanowiska, na którym określa się sposoby i cele przetwarzania danych. Funkcji i.o.d. nie należy więc łączyć na przykład z funkcjami członka zarządu, członka rady nadzorczej, dyrektora finansowego, szefa marketingu lub IT”, zob. eadem, Art. 38, [w:] RODO. Ogólne rozporzadzenie o ochronie danych. Komentarz, https://sip.lex.pl/\#/commentary/587747179/544619 (dostęp: 27.01.2020). We wcześniejszej literaturze wskazywano na adekwatność łączenia zadań przypisywanych obecnie i.o.d. z pracą na stanowiskach związanych z ochroną innych kategorii informacji lub ochroną infrastruktury służącej przetwarzaniu informacji — na przykład pełnomocnika ds. ochrony informacji niejawnych, administratora sieci komputerowej czy nawet pełnomocnika ds. jakości, zob. na przykład A. Drozd, op. cit., s. 253 n.; oraz J. Borowicz, Z problematyki..., s. 19.

${ }^{36}$ Podobnie jak na gruncie poprzednio obowiązującego stanu prawnego - zob. J. Borowicz, Obowiazek prowadzenia przez pracodawce dokumentacji osobowej i organizacyjnej z zakresu ochrony danych osobowych, „Praca i Zabezpieczenie Społeczne” 2001, nr 3, s. 4; oraz idem, Z problematyki..., s. 22. 
stosunek pracy, kierownictwo zaś pracodawcy jest terminem języka prawnego. Podporządkowanie pracownicze ujmować należy z kolei jako cechę opisową stosunku pracy charakteryzującą przedmiot zobowiązania pracownika, którym jest świadczenie pracy podporządkowanej. Należy zgodzić się z poglądem T. Liszcz, iż nie jest ono prostą odwrotnością kierownictwa pracy — podporządkowaniu pracowniczemu należy przypisać szerszy zakres ${ }^{37}$. Jak zauważa Z. Kubot, kierownictwo pracodawcy ma specyficzną treść określoną przez przepisy kodeksu pracy regulujące uprawnienia pracodawcy do wyznaczania w drodze wydawania poleceń zachowania pracownika w zakresie świadczenia pracy. Autor ten podkreślał znaczenie art. 100 § 1 k.p., który nakłada na pracownika obowiązek wykonywania poleceń pracodawcy dotyczących pracy. Mają one na celu skonkretyzowanie obowiązku świadczenia pracy umówionej poprzez wskazanie pracownikowi co, kiedy i gdzie ma robić ${ }^{38}$. W tym zakresie należy w szczególność zaznaczyć uprawnienie pracodawcy do wpływania w drodze wiążących poleceń na skonkretyzowane sposoby i metody wykonywania pracy umówionej przez zatrudnionego pracownika. Podporządkowanie pracownicze można $\mathrm{z}$ kolei ujmować w dwóch wymiarach wewnętrznym i zewnętrznym. Wymiar wewnętrzny odpowiada uprawnieniom dyrektywnym pracodawcy (wydawanie poleceń dotyczących pracy umówionej), wymiar zewnętrzny — sferze organizacyjnej wykonywania pracy umówionej (stan organizacyjnej zależności pracownika od podmiotu zatrudniającego realizowanej przez różne środki i instrumenty prawne - zwłaszcza obowiązek wykonywania pracy w miejscu i czasie wyznaczonym przez pracodawcę) $)^{39}$. Nie wyczerpuje to wszystkich aspektów podległości pracownika pracodawcy. Oprócz jego podporządkowania uprawnieniom dyrektywnym i reglamentacyjnym pracodawcy (wydawanie poleceń dotyczących pracy, regulaminów) oraz podporządkowania organizacyjnego należy wskazać podporządkowanie represyjne i dystrybutywne (stosowanie określonych przez prawo środków dyscyplinujących i nagród) ${ }^{40}$.

W świetle zapisów motywu 97 preambuły RODO intencją prawodawcy unijnego jest, aby inspektorzy ochrony danych, w szczególności będący pracownikami administratora danych, mieli możliwość wykonywania swoich obowiązków i zadań „w sposób niezależny”. Zgodnie zaś z art. 38 ust. 3, zdanie pierwsze RODO administrator oraz podmiot przetwarzający zapewniają, by inspektor ochrony danych nie otrzymywał instrukcji dotyczących wykonywania tych zadań. Istotne

37 Podkreśla to na przykład T. Liszcz, W sprawie podporzadkowania pracownika, [w:] Wspótczesne problemy prawa pracy i ubezpieczeń społecznych, red. L. Florek, Ł. Pisarczyk, Warszawa 2011, s. 114 n.

38 Zob. więcej Z. Kubot, Pojęcie kierownictwa pracodawcy, [w:] Prawo pracy a wyzwania XXI wieku. Księga jubileuszowa Profesora Tadeusza Zielińskiego, red. M. Matey, L. Nawacki, B. Wagner, Warszawa 2002, s. $236 \mathrm{n}$.

39 Zob. więcej na przykład U. Torbus, Podporzadkowanie pracownika jako cecha stosunku pracy, [w:] Wspótczesne problemy prawa..., s. $144 \mathrm{n}$.

40 Zob. więcej na przykład P. Prusinowski, Umowne podstawy zatrudnienia, Warszawa 2012, s. $51 \mathrm{n}$. 
dla zrozumienia sytuacji pracowniczej inspektora ochrony danych u danego pracodawcy jest też to, że zgodnie przepisami RODO, art. 38 ust. 3 in fine, inspektor ochrony danych bezpośrednio podlega najwyższemu kierownictwu administratora lub podmiotu przetwarzającego. Przytoczone uregulowania wyznaczają granice merytorycznej i organizacyjnej autonomii pracownika wykonującego zadania i.o.d., kształtując jego relacje z pracodawcą w sposób odbiegający od tradycyjnie ujmowanego podporządkowania pracowniczego. Inspektor ochrony danych wykonywać ma swoje obowiązki i zadania w sposób niezależny, ale w granicach obowiązującego prawa, wiedzy fachowej na temat prawa i praktyk w dziedzinie ochrony danych oraz umiejętności wypełnienia przypisanych mu prawem zadań. W tym zakresie ma on nie otrzymywać ,instrukcji”. Pojęcie „,instrukcji” nie jest tu prawnie zdefiniowane i w świetle przypisywanych mu znaczeń może budzić pewne wątpliwości. W nauce zarządzania i organizacji przez instrukcję rozumie się w szczególności opis postępowania w danej sytuacji lub podczas obsługi danego urządzenia i podkreśla się, że jest to forma wypowiedzi zawierająca na przykład wskazówki dotyczące zasad postępowania zapisane w formie tekstu ${ }^{41}$. Językowo termin ,instrukcja” oznacza przede wszystkim „zbiór przepisów ustalających sposób postępowania w jakiejś dziedzinie”, dopiero zaś w dalszej kolejności „dokładne pouczenie, wskazówkę"42. Trudno jednak zaakceptować pogląd, zgodnie z którym poszanowanie przez pracodawcę niezależności i.o.d. wyrażałoby się jedynie w powstrzymaniu się od sporządzania i przekazywania mu pisemnych zbiorów zasad postępowania w zakresie wykonywania jego obowiązków i zadań. W sposób oczywisty wywieranie wpływu na inspektora, tak jak na każdego innego pracownika, mogłoby polegać na wydawaniu zarówno ustnych, jak i pisemnych jednostkowych poleceń — także w odniesieniu do szczegółowych i konkretnych sytuacji i poszczególnych zadań czy nawet czynności cząstkowych składających się na jego zadania. Warto zauważyć, że w polskim ustawodawstwie występują przykłady regulacji prawnych znacznie adekwatniej określających zakres niezależności zawodowej (merytorycznej) pracownika. Na przykład pracownikowi — radcy prawnemu — nie można polecać wykonania czynności wykraczającej poza zakres pomocy prawnej. Radcowie prawni, rzecznicy patentowi i doradcy podatkowi zatrudnieni $\mathrm{w}$ ramach stosunku pracy nie są związani poleceniami co do treści swoich kluczowych czynności zawodowych (opinii, porad, wyjaśnień) ${ }^{43}$. Zgodnie z ogólniejszą formułą zastosowaną w odniesieniu do biegłych rewiden-

${ }^{41}$ Zob. na przykład Encyklopedia zarzadzania, https://mfiles.pl/pl/index.php/Instrukcja (dostęp: 30.01.2020).

${ }^{42}$ Zob. Stownik języka polskiego PWN, https://sjp.pwn.pl/szukaj/instrukcja.html (dostęp: 30.01.2020).

43 Zob. art. 9 ust. 4 i art. 13 ust. 1 ustawy z dnia 6 lipca 1982 roku o radcach prawnych, tekst jedn. Dz.U.2020.75; art. 11 ust. 4 ustawy z dnia 11 kwietnia 2001 roku o rzecznikach patentowych, tekst jedn. Dz.U.2019.1861; art. 27 ust. 1b ustawy z dnia 5 lipca 1996 roku o doradztwie podatkowym, tekst jedn. Dz.U.2020.130. 
tów właściciel, wspólnicy ani członkowie zarządu oraz organów nadzorczych firmy audytorskiej (zatrudniającej biegłego rewidenta) lub podmiotu powiązanego $\mathrm{z}$ tą firmą audytorską nie mogą ingerować w przeprowadzanie przez biegłego rewidenta badania sprawozdania finansowego w sposób zagrażający jego niezależności i obiektywizmowi ${ }^{44}$.

Należy przyjąć, że i.o.d. wykonuje swoje zadania i obowiązki w sposób niezależny w tym sensie, że nie może być związany poleceniami pracodawcy bez względu na ich formę, zakres i szczegółowość (polecenia ustne, pisemne, polecenia doraźne czy instrukcje postępowania), jeżeli polecenia te miałby wyznaczać w sposób wiążący jego zachowania w obszarach aktywności określonych w art. 39 ust. 1 RODO. Należy przyjąć, że w zakresie zadań określonych w tym przepisie pracownik zatrudniony na stanowisku i.o.d. zachowuje także samodzielność w zakresie doboru i planowania (organizowania) czynności służących ich realizacji. W ramach obowiązku wykonywania pracy umówionej, ze względu na szczególny jej charakter, powinien on przejawić inicjatywę w realizacji przypisanych mu prawem zadań. W tym sensie można przyjąć, że podporządkowanie pracownicze i.o.d. wyraża się w samodzielnym i niezależnym spełnianiu obowiązków nałożonych na niego przez prawo na rzecz zatrudniającego go pracodawcy ${ }^{45}$. W takim kształcie podporządkowanie pracownicze i.o.d. wpisuje się w sformułowaną w judykaturze koncepcję podporządkowania autonomicznego polegającego na wyznaczaniu/powierzaniu pracownikowi przez pracodawcę zadań do wykonania bez ingerowania w sposób ich wykonania. W tym ujęciu pracodawca określa godziny pracy i wyznacza zadania, natomiast sposób realizacji tych zadań pozostawiony jest pracownikowi ${ }^{46}$. Pozostawiając na boku szeroką dyskusję teoretyczną nad adekwatnością takiej koncepcji do obowiązującej w polskim prawie pracy konstrukcji stosunku pracy znamiennego wykonywaniem pracy pod kierownictwem

44 Zob. art. 75 ustawy z dnia 11 maja 2017 roku o biegłych rewidentach, firmach audytorskich oraz nadzorze publicznym, tekst jedn. Dz.U.2019.1421. Jednocześnie uwagę zawraca tu rozbudowany zespół przepisów określających szczegółowe zasady zachowania niezależności biegłego rewidenta w toku wykonywania czynności zawodowych — zob. art. 69 n. tej ustawy.

45 Można w tym względzie przywołać wyrok Sądu Najwyższego z dnia 12 maja 2011 roku, UK 20/11, OSNP 2012, nr 11-12, poz. 145, teza 2, w którym podniesiono między innymi, że w modelu ,autonomicznego” podporządkowania pracowniczego osoby zarządzającej zakładem pracy podległość wobec pracodawcy (spółki z ograniczoną odpowiedzialnością) wyraża się w respektowaniu uchwał wspólników i wypełnianiu obowiązków płynących z kodeksu spółek handlowych.

46 Zob. powszechnie przywoływany wyrok Sądu Najwyższego z dnia 7 września 1999 roku, I PKN 277/99, OSNP 2001, nr 1, poz. 18. Zob. też wyroki, w których Sąd Najwyższy podkreśla związek autonomii pracownika z rodzajem wykonywanej pracy, pełnioną funkcją lub stanowiskiem, wskazując na zawody twórcze czy przypadki pracy na stanowiskach kierowniczych i samodzielnych: wyrok z dnia 30 maja 2017 roku, I PK 171/16, LEX nr 2329471, zob. pkt 2 tezy; wyrok z dnia 8 czerwca 2017 roku, I UK 240/16, LEX nr 2375939, zob. teza 1 i 2; wyrok z dnia 6 grudnia 2016 roku, UK 439/15 LEX nr 2188634, zob. pkt 1 tezy; wyrok z dnia 13 kwietnia 2016 roku, II PK 81/15 LEX nr 2026397. 
pracodawcy i w miejscu i czasie przez niego wyznaczonym ${ }^{47}$, należy stwierdzić, że to sam ustawodawca kształtuje status pracowniczy i.o.d. w sposób gwarantujący mu szeroką autonomię (niezależność i samodzielność) w wykonywaniu przypisanych mu obowiązków. Tworzy to podstawę do zakwalifikowania stosunku pracy, w którego ramach zatrudniony jest i.o.d., do kategorii nietypowych stosunków pracy ${ }^{48}$.

Dla potrzeb określenia pozycji organizacyjnej i.o.d. zachowują aktualność spostrzeżenia poczynione na gruncie poprzednio obowiązującego stanu prawnego, w którym pozycję organizacyjną ówczesnego a.b.i. porównywano do pozycji pełnomocnika do spraw ochrony informacji niejawnych czy pracowników wykonujących wolne zawody, takie jak radca prawny, rzecznik patentowy czy doradca podatkowy ${ }^{49}$. Przedstawiciele tych zawodów zatrudnieni w ramach stosunku pracy mają zajmować stanowiska podległe bezpośrednio kierownikowi jednostki organizacyjnej/kierownikowi podmiotu zatrudniającego ${ }^{50}$. W przypadku i.o.d. mowa jest o podleganiu ,najwyższemu kierownictwu”. W związku z brakiem definicji pojęcia najwyższego kierownictwa E. Bielak-Jomaa wskazuje, że w jego zakres mogą wchodzić osoba albo grupa osób, które kierują organizacją, wskazują strategiczne cele i misję jej działania oraz nadzorują działania organizacji. Najwyższym kierownictwem może być na przykład prezes firmy, dyrektor szkoły, w wypadku spółek kapitałowych - zarząd ${ }^{51}$. Rozpatrując to w kontekście sytuacji pracowniczej i.o.d., należy skonstatować, że w sensie organizacyjnym powinien on być podległy bezpośrednio pracodawcy albo osobie lub organowi zarządzającemu zakładem pracy w imieniu pracodawcy. Funkcją takiego, a nie innego ukształtowania pozycji organizacyjnej inspektora ochrony danych w zakładzie pracy jest, podobnie jak w przypadku wymienianych wolnych zawodów, zagwarantowanie mu maksymalnej w warunkach wykonywania pracy skooperowanej niezależności i samodzielności w realizowaniu zadań wchodzących w zakres pracy umówionej, w szczególności z uwzględnieniem możliwości efektywnego nadzorowania działań osób przetwarzających dane osobowe u danego pracodawcy ${ }^{52}$.

47 Zob. na przykład szeroki przegląd wypowiedzi doktryny w Wspótczesne problemy prawa...

48 O pojęciu nietypowych stosunków pracy zob. na przykład Z. Kubot, Szczególne formy zatrudnienia i samozatrudnienia, [w:] Szczególne formy zatrudnienia, red. Z. Kubot, Wrocław 2000, s. $6 \mathrm{n}$.

49 Zob. J. Borowicz, Sytuacja prawna..., s. 20.

50 Zob. art. 14 ust. 2 ustawy z dnia 5 sierpnia 2010 roku o ochronie informacji niejawnych, tekst. jedn. Dz.U.2019.742; art. 9 ust. 1 i ust. 3 ustawy z dnia 6 lipca 1982 roku o radcach prawnych, art. 4 ust. 4 ustawy z dnia 11 kwietnia 2001 roku o rzecznikach patentowych, art. 31 ust. 1a. ustawy z dnia 5 lipca 1996 roku o doradztwie podatkowym.

51 Zob. E. Bielak-Jomaa, Art. 38...

$52 \mathrm{Na}$ zabezpieczenie możliwości tego typu nadzorowania uwagę zwraca P. Fajgielski, Komentarz do rozporządzenia $\mathrm{nr}$ 2016/679 w sprawie ochrony osób fizycznych w zwiąku z przetwarzaniem danych osobowych $i w$ sprawie swobodnego przeptywu takich danych oraz uchylenia dy- 
Istotne z punktu widzenia zagwarantowania niezależności i.o.d. wykonującego swoje obowiązki w ramach stosunku pracy jest uregulowanie art. 38 ust. 3 RODO, zdanie drugie, w którym postanawia się, że inspektor ochrony danych nie jest „odwoływany ani karany przez administratora ani podmiot przetwarzający za wypełnianie swoich zadań”. Umieszczenie postanowienia wskazującego zakaz odwołania i.o.d. w kontekście zatrudnienia pracowniczego pozwala odnieść się w jego interpretacji do konstrukcji wzmożonej ochrony trwałości stosunku pracy. Warto nadmienić, że już w 2004 roku na gruncie przepisów u.o.d.o. 1997 postulat jej wprowadzenia, gwoli prawnego zagwarantowania niezależności ówczesnego a.b.i., formułował A. Drozd ${ }^{53}$. Akceptując, co do zasady, celowość i wagę rozwiązania wprowadzonego w art. 38 ust. 3 RODO, zdanie drugie, należy zgodzić się z zastrzeżeniami doktryny w kwestii precyzji zastosowanych $\mathrm{w}$ tym przepisie sformułowań. Na przykład P. Fajgielski słusznie podnosi, że brzmienie tego przepisu sugeruje, że wobec i.o.d. nie mogą być wyciągane konsekwencje za jakiekolwiek działania, które są realizacją jego zadań. Należy zgodzić się z poglądem autora, że nie można uznać takiej wykładni za prawidłową. Jej przyjęcie oznaczałoby bowiem niemożność zastosowania jakichkolwiek sankcji w przypadku nienależytego wykonywania zadań przez i.o.d. Trzeba zatem przyjąć, że nie może on być odwołany ani karany za prawidłowe, aczkolwiek w konkretnym przypadku być może niewygodne dla pracodawcy wypełnianie swoich zadań. Idąc tokiem rozumowania autora, w przypadku zawinionych błędów i uchybień i.o.d. wyrażających braki jego wiedzy fachowej na temat prawa i praktyk w dziedzinie ochrony danych lub brak umiejętności wypełnienia przypisanych przez prawo zadań, a zwłaszcza w sytuacji niepodjęcia wymaganych działań lub naruszenia tajemnicy danych osobowych (niewykonanie lub nienależyte wykonania pracy umówionej), pracodawca może zastosować wobec i.o.d. przewidywane w przepisach prawa i mieszczące się w zakresie szeroko rozumniej odpowiedzialności pracowniczej środki generujące po stronie pracownika negatywne skutki/dolegliwości, z rozwiązaniem umowy o pracę włącznie ${ }^{54}$. Należy także pamiętać, że ochrona przysługująca i.o.d. na mocy art. 38 ust. 3 RODO, zdanie drugie, nie obejmuje sytuacji naruszenia obowiązków pracowniczych niemających charakteru naruszenia jego prawem określonych zadań, w szczególności przy spełnieniu przesłanek rozwiązania umowy o pracę bez wypowiedzenia z winy pracownika (art. $52 \S 1$ pkt 1 k.p.) albo przesłanek odpowiedzialności porządkowej (art. 108n k.p.) lub materialnej (art. 114 k.p. $)^{55}$. Inspektor ochrony danych jako pracownik w rozumieniu art. 2 k.p. ma obowiązek podporządkować się wymierzanym mu sankcjom, których stoso-

rektywy 95/46/WE (ogólne rozporządzenie o ochronie danych), art. 38, [w:] Ogólne rozporządzenie o ochronie danych...

53 Zob. A. Drozd, op. cit., s. 253.

54 Zob. P. Fajgielski, Komentarz do rozporzadzenia, art. 38...; podobnie E. Bielak-Jomaa, Art. $38 \ldots$

55 Na szerszy wymiar odpowiedzialności i.o.d. wskazuje E. Bielak-Jomaa, Art. 38... 
wanie jest wyrazem kierowniczych uprawnień dyscyplinarnych/represyjnych pracodawcy. Innymi słowy pracownik ten pozostaje w układzie podporządkowania represyjnego będącego jednym $\mathrm{z}$ aspektów podporządkowania pracowniczego ${ }^{56}$.

\title{
THE LEGAL SITUATION OF A DATA PROTECTION OFFICER EMPLOYED UNDER AN EMPLOYMENT RELATIONSHIP - SELECTED ISSUES
}

\author{
Summary
}

In accordance with the provisions of Article 37(1) of the Regulation (Eu) 2016/679 Of The European Parliament And Of The Council of 27th April 2016 on the protection of natural persons with regard to the processing of personal data and on the free movement of such data, and repealing Directive 95/46/EC (General Data Protection Regulation - GDPR) the controller and the processor shall designate a data protection officer in any case where: a) the processing is carried out by a public authority or body, except for courts acting in their judicial capacity; (b) the core activities of the controller or the processor consist of processing operations which, by virtue of their nature, their scope and/or their purposes, require regular and systematic monitoring of data subjects on a large scale; or (c) the core activities of the controller or the processor consist of processing on a large scale of special categories of data pursuant to Article 9 GDPR and personal data relating to criminal convictions and offences referred to in Article 10 GDPR. In other cases, the designation of a data protection officer is the right of the personal data administrators or processors. In accordance with the provisions of Article 37(6) GDPR the data protection officer may be a staff member of the controller or processor, or fulfil the tasks on the basis of a service contract. Neither GDPR nor the Polish Law of 10th May 2018 on the Protection of Personal Data define the legal form for the employment of data protection officer. It must therefore be assumed that he may be employed under a contract of employment as an employee within the meaning of the provisions of the Polish Labour Code. The provisions of the GDPR specify specific tasks of the data protection officer and designate a special position in the organisational structure of the entity in which personal data are processed. The data protection officer reports directly to the highest management level of the controller or the processor (e.g. head of the organisational unit or to a natural person that is the administrator of personal data). The data protection officer, in the exercise of his tasks of law retains a wide autonomy and independence in the workplace and the employer is obliged to provide him with independence in connection with the performance of his tasks. The controller and processor shall ensure that the data protection officer does not receive any instructions regarding the exercise of those tasks. The main consequence of this is reducing the possibility of managing the work of the data protection officer by using the commands of the employer. It should be considered that the data protection officer is employed in an atypical employment relationship.

Keywords: GDPR, data protection officer, employee, employer, obligation to perform the commands of the employer, personal data administrator, protection of personal data, atypical employment relationship

$56 \mathrm{Na}$ temat podporządkowania represyjnego zob. więcej P. Prusinowski, op. cit., s. $58 \mathrm{n}$. Należy uznać, że na potrzeby analizy porządkowania pracowniczego i.o.d. zachowują aktualność uwagi dotyczące sytuacji pracowniczej a.b.i. w J. Borowicz, Z problematyki..., s. 20-23. 


\section{BIBLIOGRAFIA}

Bielak-Jomaa E., Art. 37, [w:] RODO. Ogólne rozporządzenie o ochronie danych. Komentarz, https://sip.lex.pl/\#/commentary/587747178/544618 (dostęp: 27.01.2020).

Bielak-Jomaa E., Art. 38, [w:] RODO. Ogólne rozporzadzenie o ochronie danych. Komentarz, https://sip.lex.pl/\#/commentary/587747179/544619 (dostęp: 27.01.2020).

Borowicz J., Obowiązek prowadzenia przez pracodawce dokumentacji osobowej i organizacyjnej z zakresu ochrony danych osobowych, „Praca i Zabezpieczenie Społeczne” 2001, nr 3.

Borowicz J., Sytuacja prawna pracownika przetwarzajacego dane osobowe w ramach wykonywania obowiązów ze stosunku pracy, [w:] Z aktualnych problemów prawa pracy i prawa socjalnego, red. H. Szurgacz, („Prawo” 307), Wrocław 2009.

Borowicz J., Z problematyki zatrudnienia administratora bezpieczeństwa informacji, „Praca i Zabezpieczenie Społeczne" 2016, nr 12.

Drozd A., Ustawa o ochronie danych osobowych. Komentarz. Wzory pism i przepisy, Warszawa 2004.

Fajgielski P., Komentarz do rozporządzenia $n r$ 2016/679 w sprawie ochrony osób fizycznych w związ$k u$ z przetwarzaniem danych osobowych $i w$ sprawie swobodnego przeplywu takich danych oraz uchylenia dyrektywy 95/46/WE (ogólne rozporzadzenie o ochronie danych), art. 37, [w:] Ogólne rozporzadzenie o ochronie danych. Ustawa o ochronie danych osobowych. Komentarz, https://sip.lex.pl/\#/commentary/587773181/57061 (dostęp: 27.01.2020).

Fajgielski P., Komentarz do rozporządzenia nr 2016/679 w sprawie ochrony osób fizycznych w związ$k u$ z przetwarzaniem danych osobowych $i$ w sprawie swobodnego przeptywu takich danych oraz uchylenia dyrektywy 95/46/WE (ogólne rozporzadzenie o ochronie danych), art. 38, [w:] Ogólne rozporzadzenie o ochronie danych. Ustawa o ochronie danych osobowych. Komentarz, https://sip.lex.pl/\#/commentary/587773182/570622 (dostęp: 27.01.2020).

Kubot Z., Pojęcie kierownictwa pracodawcy, [w:] Prawo pracy a wyzwania XXI wieku. Księga jubileuszowa Profesora Tadeusza Zielińnkiego, red. M. Matey, L. Nawacki, B. Wagner, Warszawa 2002.

Kubot Z., Szczególne formy zatrudnienia i samozatrudnienia, [w:] Szczególne formy zatrudnienia, red. Z. Kubot, Wrocław 2000.

Liszcz T., W sprawie podporzadkowania pracownika, [w:] Wspótczesne problemy prawa pracy i ubezpieczeń społecznych, red. L. Florek, Ł. Pisarczyk, Warszawa 2011.

Mednis A., Ustawa o ochronie danych osobowych. Komentarz, Warszawa 1999.

Prusinowski P., Umowne podstawy zatrudnienia, Warszawa 2012.

Torbus U., Podporzadkowanie pracownika jako cecha stosunku pracy, [w:] Wspótczesne problemy prawa pracy i ubezpieczeń społecznych, red. L. Florek, Ł. Pisarczyk, Warszawa 2011. 